Article

\title{
Similar but Superior: Rhetoric of Coexistence Employed by Religions in Jeju Island, Korea ${ }^{\dagger}$
}

\author{
Yohan Yoo \\ Department of Religious Studies, Seoul National University, Seoul 08826, Korea; yohanyoo@snu.ac.kr \\ + This article relies on many of the materials that I used in a paper that was published in Korean in a Korean \\ journal (Yoo 2012). Unlike the former work that devoted many pages to a general explanation of religious \\ topography of Jeju Island, this article focuses on the rhetoric of coexistence employed by Jeju religions.
}

Received: 25 March 2020; Accepted: 15 April 2020; Published: 18 April 2020

\begin{abstract}
Religions in Jeju, South Korea, have sometimes been in conflict with each other, but have generally coexisted peacefully. In a situation where diverse religions share an island that is isolated from the mainland, they have emphasized that they are similar yet superior to their rivals. Religions that were imported to Jeju, including Confucianism, Buddhism, and Christianity, have tried to make themselves look familiar to Jeju people on the basis of people's knowledge of preexisting religions. These religions sometimes embraced rituals of preexisting religions to which people were strongly attached. The Jeju indigenous religion has also acknowledged that the ideas and practices of Buddhism and Confucianism have remarkable similarities to those of its own. Simultaneously, each religion in Jeju has claimed its superiority over others. Religions in Jeju have argued that other religions' partial truth and limited value are in sharp contrast with the complete truth and superior value of their own. They have asserted that only they can provide the proper way of keeping the order of the universe or attaining salvation of human beings. This common rhetoric that "my religion is similar but superior to other religions" has been repeated in Jeju, in order to persuade people outside the religion to accept or at least approve it on the one hand, and to maintain the peaceful coexistence with other religions on the other hand.
\end{abstract}

Keywords: religious conflicts; coexistence of religions; Korean religions; Jeju Island

\section{Introduction}

Jeju-do (Jeju) is the largest island in Korea and one of the nine provinces that constitute the country $^{1}$. It is the smallest province, with a population of about 583 thousand people over 1848 square kilometers, as of 2015. Considering the entire South Korean population of about 50 million over 99,373 square kilometers, Jeju Province is quite small. As Jeju is an island that is about $100 \mathrm{~km}$ away from the mainland, its religious tradition has developed its own distinctive features. Most notably, the indigenous shamanic religion is still strong and active. The official Korean census does not indicate the number of people who profess the indigenous religion because the questionnaire of the census deals only with so-called institutionalized religions. Those who regularly participate in communal or family shamanic rituals that are mainly performed or led by simbang (Jeju shaman), often about half of the inhabitants in villages in the countryside, have no option but to state that they have "no religion" on the census form if they do not go to church or Buddhist temple. A large portion of those who claim

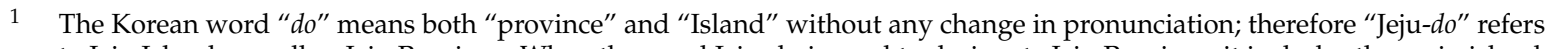
to Jeju Island as well as Jeju Province. When the word Jeju-do is used to designate Jeju Province, it includes the main island, namely Jeju Island, and 63 smaller nearby islands among which eight are inhabited. 
to have no religion, about $58 \%$ of the whole Jeju population according to the November 2015 census, believe in the efficacy of the rituals and the divination practiced by simbang. In addition, many among those who identify themselves as Buddhists, $23.9 \%$ according to the same census, also often participate in the indigenous rituals (Statistics Korea 2016).

Another important feature of the religious topography of Jeju is the relatively weak influence of Christianity. Christianity is the biggest religion in South Korea as shown in the November 2015 census that reports $27.7 \%$ of the population as Christian. The rate of Buddhists stands at $15.5 \%$ throughout the country. But in Jeju, the number of Christians is much smaller than that of Buddhists. Christians in Jeju make up only $17.9 \%$ of the whole population, while Buddhists constitute $23.9 \%$. In addition, Protestantism in Jeju has not been as successful as on the mainland. While Protestants constitute 19.7\% of the national population, the rate of Protestants in Jeju stands at $10.0 \%$. The Catholic population was the same, $7.9 \%$, in the national population and in Jeju.

Therefore, the indigenous shamanic religion, Buddhism, and Christianity now coexist without serious trouble in Jeju, showing the conspicuous characteristic of its religious topography as there is maintenance of a range of religions, including the strong indigenous shamanic religion, fairly strong Buddhism, and relatively weak Christianity. Though few people identify themselves as Confucians, the influence of Confucianism still remains in the ways of thinking and acting of Jeju people, which should be also considered when research on Korean religion is carried out.

In this article, I will focus on the rhetoric that has been often employed by religions in Jeju to convince people of their similarity to others and at once to claim their superiority over others. They have emphasized both common elements of themselves with others and their own superiority when they try to explain their relationship with other religions. Imported religions, especially Buddhism and Confucianism, have acknowledged some important elements of the indigenous shamanic religion and appropriated them for the purpose of making themselves look familiar to residents who have been holding fast to shamanism. Religions in Jeju selectively borrowed certain elements from other religions which they recognized as true or valuable, and appropriated them as effective tools for broadening their influence.

This rhetoric is based on comparisons performed by religions, which "tells us how things might be conceived" rather than "how things are," and which is in fact very often "apologetic" though it is seemingly made for intellectual understanding (Smith 1990, pp. 52, 143). Apologetic rhetoric of a religious tradition employs a way of comparison that highlights the commonality between itself and other religions in order to make itself look familiar to others. In Jeju, the common elements that were found in other religions helped a religion make itself look familiar to its possible future adherents. This comparison also emphasizes the comparing religion's superiority over the others. Religions of Jeju that came into contact with other religions acknowledged and appreciated some elements of other religions for the purpose of accentuating their own superiority over others. While other religions vaguely showed the "partial truth" from the common elements, the religion persuading others often argues that only it manifests clearly the whole truth. As Jonathan Z. Smith indicates, religions often stress sameness in comparing themselves with others in order to justify themselves and underscore others' inferiority (Smith 1990, pp. 54-84).

I will demonstrate that this rhetoric of commonality and superiority has been employed not only for attracting people adhering to other religions but also for maintaining the peaceful coexistence with others. In the second section, the "similar but superior" rhetoric of Confucianism and Buddhism will be examined. Religions in Jeju have needed to convince Jeju people of their similarity to others because it was the most efficient way to be incorporated in the cosmology shared by Jeju people. Furthermore, they needed to prove their raison d'être and to differentiate themselves. In the third section, it will be shown that the "similar but superior" rhetoric is also to be found in Christianity in Jeju. This rhetoric has been needed to attract people outside the religion, to manage its adherents, and to maintain a peaceful state of coexistence. In the fourth section, views of the indigenous shamanic religion on other religions will be described. Though Jeju shamans clearly recognize the similarity of the Jeju 
indigenous religion to Buddhism and Confucianism, they also emphasize the superiority of their own religious system.

To demonstrate the commonality and superiority employed by Jeju religions, I tried to examine related written materials as thoroughly as possible, ranging from Jeju indigenous myths to books written by Confucian scholars during the Joseon period, and to a book written by the first Korean native Catholic priest in Jeju. At the same time, I tried to observe what religious people in Jeju think about other religions, spending quite a long time with them. I also interviewed four Jeju shamans, two Buddhist nuns and one monk, a Protestant pastor, and two Catholic priests working in Jeju. Though the interviews may not be ideal for a source, they are very useful for the aim of this article.

\section{2. "Similar but Superior" Rhetoric of Confucianism and Buddhism in Jeju}

\subsection{A Short History of Religions in Jeju}

The indigenous shamanic religion is more alive in Jeju than in any other Korean provinces and plays the most important role in Jeju, even though Buddhism, Confucianism, and Christianity have entrenched themselves in Korea through a long history. Confucianism and Buddhism have not had serious problems with the Jeju indigenous religion, in spite of their effort to exhort Jeju indigenous people to accept their ideas and practices. A short history of Buddhism and Confucianism in Jeju would be helpful for understanding this situation (for more information, see (Yoo 2012)).

It is believed that Buddhism started to penetrate Jeju in earnest in the 12th century, whereas Buddhism was imported into Korea in the 4th century. Jeju people were not pressured to convert to Buddhism or Confucianism during the Goryeo Dynasty (918-1392). Buddhism began to influence Jeju people under the direct rule of the Mongolian Empire for about 100 years from 1273, when Mongol style Buddhism (Lamaism), which originated in Tibet, was brought into Jeju when the Mongols dispatched approximately 1700 soldiers to the island. Many Jeju people must have had experiences with the Buddhism professed by the Mongol soldiers, considering that the number of Jeju people working for the temple Beophwasa was 280 and that for the temple Sujeongsa was 130, both of which were built by and for Mongol soldiers. ${ }^{2}$ The influence of the religion rapidly weakened after the Mongols had retreated. Buddhism at an institutional level seems to have virtually disappeared in Jeju by the early 18th century. According to magistrate Yi Hyeongsang, who proceeded to his Jeju post in 1702, though there existed many ruins of old Buddhist temples, there were only three standing temples in which no monks resided (Yi 2009, pp. 113-14).

The Joseon Dynasty, established in 1392, espoused Neo-Confucianism, which was developed by Chinese scholars of the Song Dynasty and especially systematized by Zhu Xi (Smith 1995, p. 284; Tu 1993, pp. 180-82). Confucianism was imported in earnest to Jeju by local officials who were Confucian scholars dispatched by the Joseon government. To Confucian elites of Joseon, rituals of both Buddhism and the indigenous shamanic religion were eumsa, a word referring to rituals conducted against the proper procedure, practiced by a person of an inappropriate hierarchical position, or offered to undeserving spirits (Choe 2007, p. 48; for the importance of rituals for Confucian scholars of Joseon, see (Smith 2004, p. 170)). Confucian scholars disapproved of Buddhist and shamanic rituals and tried to replace them with "impeccable Confucian rituals" (Walraven 1999, p. 195).

However, in spite of this effort of the Korean scholar-officials to assign an exclusive position to Confucianism from the late $14^{\text {th }}$ century onwards, it was only by the mid-17th century that the domestic and communal rituals, which used to be performed in shamanistic ways, were Confucianized in the mainland. In Jeju, it was not until the early 19th century that Confucian rituals became common. Ancestral rites began to follow the Confucian way, poje, Confucianized fertility rites, were adopted and

2 The population of the island in the early 15th century is estimated to be around 60,000, according to the Annals of Joseon Dynasty. Though there is no document regarding its population in the previous century, it is thought that it was less than that, of the 15th century. See (Cho 2005, pp. 53-55). 
seen as proper communal rituals by most villages, and the family and marriage system came to follow Confucian rules (Hyeon 2009, pp. 192, 210-11, 276).

\subsection{The Rhetoric of Confucianism in the Late Joseon Period}

Though it is true that Confucianism, Buddhism, and the indigenous shamanic religion were also in competition with one another during the Joseon period (1392-1910), they also took different complementary roles at times (Choe 2007, pp. 48, 62, 66, 69-70, 73). The ruling class of Joseon, which firmly espoused Confucianism, not only tolerated but also accepted Buddhism and the indigenous religion at least in part. The elites of Joseon subordinated Buddhism and the indigenous religion to Confucianism in the Confucian world order system and secured the superiority of Confucianism over these two preexisting religions, for which the "similar but superior" rhetoric was employed, though generally implicitly.

Reliance on the indigenous shamanic religion by the commoners was heavier in Jeju than in the mainland, whereas the influence of Buddhism was small during the Joseon period. It was, therefore, that Confucian elites in Jeju in the late Joseon period mainly emphasized the similarity and superiority of Confucianism over the shamanic religion rather than Buddhism. In 1702, magistrate Yi Hyeongsang estimated the power of the indigenous religion to be 100 times stronger than that of the mainland. He said that the number of shamans amounted to 1000, which was quite huge considering that the number of households in Jeju at that time was about 9200 (Yi 2009, p. 117).

Of course, the indigenous religion experienced intermittent persecutions in Jeju. Magistrate Yi, who was a very faithful Confucian scholar, tried to repress the shamanic religion during his short incumbency of one year and three months. He strictly prohibited shamanic rituals, destroyed 129 shamanic shrines that fell under his jurisdiction, and forced 285 simbang to work in agriculture. This action is understandable because during the Joseon period, Confucian scholars considered rituals performed by shamans to be of the lowest kind among non-Confucian rituals, eumsa.

However, the persecutions were temporary. Magistrates who came to Jeju after Yi rebuilt shrines and resurrected shamanic rituals. Most officials approved indigenous rituals and some officials even supported or hosted them. For example, some shamanic rituals including ipchungut, which is performed to celebrate the beginning of spring, were supported by magistrates and performed within the government building and its yard. A shamanic shrine that is called "the shrine for the goddess of the government office" was built in the courtyard of a local government building complex of the Joseon period. As they were integrating shamanic rituals into the Confucian system, the Confucian officials did not consider it wrong to revere the local deities. By invoking the similarity of the two religions, they could reach and edify the indigenous people.

It should be noted that the Confucian officials of Joseon, including those of Jeju, could approve the shamanic religion because they regarded its view of the universe as similar to that of Confucianism. The indigenous religion was accepted as tolerable and controllable within the ritual system unified under Confucianism. Walraven rightly points out, "The cosmology of Neo-Confucianism does contain elements that might provide a basis to harmonize Confucianism and popular religion." He continues,

Confucian concepts, sophisticated as they might be in their full philosophical elaboration, were expressed at times in simple terms hardly different from popular beliefs. The popular view of the universe is less systematized, less ordered, but basically it is similar: the world in which humankind live and the world of spirits and gods operate according to the same principles, and there is no great transcendental divide between the two. In both the Confucian and the popular visions, human fortune and misfortune are linked to the invisible other sphere. (Walraven 1999, pp. 166-67)

As it was recognized that Confucianism and shamanism have similar perspectives on the universe, the Joseon government, while officially disparaging the latter, allowed common people to resort to shamans and perform shamanic rituals, which were given a lower hierarchical position beneath 
Confucianism. On the other hand, because of this similarity, common people could easily replace their traditionally conducted shamanic rituals with Confucian ones. The similar but superior rhetoric employed by the Confucian elites of Joseon is based on this firm belief in the hierarchical relationship between religions, in which Confucianism, Buddhism, and the shamanic religion were considered similar but Confucianism was superior to the others.

Most commoners in Jeju who had not been acquainted with Confucianism could accept it because to them it was not totally different from the shamanic religion. They started to perform Confucian rituals since the early 19th century. The indigenous rituals of Jeju have often become a part of the Confucian ritual, demonstrating that the similar but superior rhetoric of Confucianism was successful. Some rituals that have been performed for generations clearly reflect the coexistence of the two religions and the superior status of Confucianism. For example, Confucian-style domestic offering rituals include not only an ancestral ceremony but also offering rituals for shamanic household gods. The head officiant offers a table of food to the god of the main gate of the house. The goddess of the kitchen is also the recipient of a small food offering by the wife of the head officiant. In some families, the serpent gods enshrined in the backyard and the storeroom are also served, though this practice is getting rare nowadays (Hyeon 2009, pp. 226-27). In this ritual, indigenous gods are celebrated but they are not the main object of worship. They are supposed to share the food that is prepared for ancestors. Indigenous rituals are manifestly incorporated into the Confucian ancestral ceremony. It shows that the two religions can coexist in the same ritual and also that Confucianism is superior.

Another example can be found in many villages that have accepted the complete Confucian way of community rituals. Here, male members take charge of the Confucian ritual poje and most female members of the villages still participate in shamanic community rituals (Hyeon 2009, pp. 253-54). Just as in other regions, only male members of a community or family can become officiants or celebrants of Confucian rituals. Females are supposed to support rituals by preparing food or cleaning afterward. But women take the lead in shamanic rituals as lay leaders. ${ }^{3}$ In Haeandong, Jeju City, the shamanic community ritual dangje (or danggut, ritual of Shamanic shrine) is conducted by women in January and the Confucian community ritual poje by men in July. In Aewolli village, right after the Confucian poje is finished, women carry out dangje, reusing the food offered during the former. The two villages show the realization of "similar but superior" rhetoric of Confucianism.

In both villages, males, who were regarded as superior to female members and were representatives of families and communities during the Joseon period, take charge of the Confucian ritual, while females take on roles in the shamanic ritual. In Aewolli, food is not separately prepared for the shamanic ritual but the food for the Confucian ritual is reused. It can be said that people of these villages accepted not only the similarity between Confucian rituals and shamanic ones but also the superiority of Confucianism over the indigenous religion.

Confucianism and shamanism managed to coexist under one unified ritual system because they basically shared the same cosmology. Confucian officials often officially recognized this similarity, and Jeju people easily accepted Confucian ideals and its ritual system. In a sense, officials from Seoul who tried to propagate Confucianism exploited this similarity for their agenda. Most of them not only allowed but also supported some shamanic rituals. Shamanic rituals were even performed in the government building, unimaginable on the mainland. In Jeju, where shamanism was said to be 100 times stronger, borrowing magistrate Yi's description, than on the mainland, simple expulsion or repression of it would not be the wisest solution when proselytizing Confucian values. Confucianism was likely to have been able to spread in Jeju because people were persuaded that it was not fundamentally different from the indigenous religious tradition. Furthermore, Confucianism extended its power most

3 Both men and women participated in the shamanic community ritual dangje before the Confucian culture took root in Jeju in the early 19th century. It is thought that due to Joseon's policy of repressing shamanism, men started to avoid becoming shamans and as a result, women came to constitute the majority of shamans. In Jeju, however, the number of male simbang was higher than that of female simbang until recently, although nowadays the ratio of the latter is increasing. 
efficiently by accommodating the similarities it shared with the indigenous religion and by having people participate in the unified system. Therefore, the Confucian officials' acknowledgement of similarity was necessary for its existence and coexistence with the indigenous belief.

In addition, in this integrated system, of which Confucian officials approved and even made use of, Confucianism was granted a higher status than the indigenous religion. They argued that shamanism was not considered appropriate in representing truth, since it represented only "partial truth." While recognizing that there was at least some truth in the indigenous religion, Confucianists did not fully accept the shamanic indigenous religion as a true and proper way for maintaining order of the universe. Though it was not completely wrong, and thus not absolutely intolerable, it was surely not the proper way for serving gods or spirits. The superiority of Confucianism was firmly articulated. Confucian officials used the similar but superior rhetoric for coexistence with the indigenous religion.

\subsection{The Rhetoric of Buddhism in the 20th Century}

Following the downfall of Joseon in 1910, Confucianism was no longer officially supported. Though Confucian rituals still survive to this day, the influence of Confucianism became quite minimal in Korea including Jeju. In contrast, Buddhism has been flourishing in Jeju since 1908, when a Buddhist temple was established by a monk named An Bongnyeo. Buddhism was not a totally new religion to Jeju people at that time. As will be explained further, the influence of Buddhism has remained in myths and rituals of the indigenous Jeju religion, which may be one of the reasons why Buddhism could grow rapidly, whereas it was almost unseen in Jeju during the late Joseon period. It should also be noted that Buddhism's characteristic of readily adapting to indigenous beliefs and rituals helps indigenous people feel friendly toward Buddhism.

In addition, Buddhism is an institutionalized religion that looks much more advanced and sophisticated than the indigenous religion. Many people who used to consult simbang and invite them for shamanic rituals have gradually converted to Buddhism, and now go to Buddhist temples to consult monks. A nun of Bultapsa Temple said during an interview that more and more people who had been going to both Buddhist temples and shamanic shrines nowadays come only to the temple. ${ }^{4}$ She told of an old female lay member of Bultapsa who quit going to a shamanic shrine of the village and stopped seeing a simbang because her son and daughter-in-law did not want her to be "superstitious." A monk of Haeunsa also said that people often come to him instead of going to a simbang because he takes charge of traditional indigenous ritual services that used to be performed by simbang.

When a Buddhist monk undertakes an indigenous ritual, the original purpose of the ritual remains as it is but the monk performs it in a Buddhist way. For instance, the monk of Haeunsa often officiates antaekgut, which is a domestic shamanic ritual conducted for the purpose of worshipping and appeasing the indigenous household gods by offering food to them. Instead of worshipping and offering food, he recites Buddhist sutras in some parts of the house, where important gods are believed to reside, such as the front entrance, kitchen, and main room. The monk said that some Jeju people have asked him to perform jae, a kind of Buddhist service, not for the original purpose, which is to pray for the repose of the dead people's souls, but for good fortune and wellbeing of the living family members. According to him, many monks of Jeju acknowledge that if a monk is to become successful in Jeju, he should become half shamanic. It seems that some Jeju people expect Buddhist rituals to replace the indigenous rituals and to assume the roles that the indigenous rituals have played.

There are many examples of indigenous shamanic rituals that have been modified in a Buddhist way (see Kim et al. 2007, pp. 31, 33, 36, 75, 93, 100, 105, 111, 133, 184). When a family decides to remove

4 The interviews cited in this article were conducted between March and July 2010. All of the interviewees cited in this article were aware that I would use the interview for academic research. All of them were religious specialists, including two Buddhist monks, two Catholic priests, two Protestant pastors, and four simbang. 
a representation of the serpent god, which is usually made of bricks and straw and enshrined in a backyard or storehouse, ${ }^{5}$ traditionally a simbang had been invited to perform a ritual for sending away the spirit to the otherworld. But nowadays, many households that decide not to keep the symbolic bodies invite a Buddhist monk. The monk performs a ritual for sending the spirit to the otherworld and keeps the symbolic figurine in a temple along with mortuary tablets of dead persons. Many domestic rituals, including antaekgut for asking domestic gods to give the family peace and safety, funerary rites, building rituals for inducing the homesite god to enter a newly built house, and tosinje for serving the homesite god to ask him to guarantee fecundity of the household, are often officiated by Buddhist monks in a syncretic form born from the fusion of Buddhism and shamanism. Buddhist monks sometimes perform neokdeurim, which is a ritual for recalling a part of the soul that has gone out of the body of a person who experienced a shocking accident. Furthermore, when a person or family gets dongti, pollution or danger that results from violating taboos, nowadays Buddhist monks perform a kind of purification ritual that used to be conducted only by simbang. In some villages, even community rituals like yowangje, which used to be carried out by simbang and villagers for the purpose of worshiping the sea god and praying for a good haul, are now performed by reciting a Buddhist prayer asking the Buddha to command the sea god to give abundant seafood to the villagers.

The indigenous rituals could have been replaced by Buddhist rituals because Jeju people recognize continuity between the indigenous religion and Buddhism. Buddhism, like Confucianism, has a cosmology that is not distinctive from that of the indigenous religion. Buddhism and the indigenous religion have in common the idea that fortune and misfortune of human beings are influenced by the gods and spirits. Above all, they emphasize a smooth transfer of a dead person's spirit to the other world and claim that its status and wellbeing can be promoted by rituals performed by the living. On the basis of these similarities, Buddhism has accepted many deities and rituals of the indigenous religion in Korea. Buddhism has removed Jeju people's reluctance to invoke blessings and perform rituals in Buddhist ways by spontaneously switching indigenous rituals to Buddhist ones. In other words, Buddhism made many Jeju people convert to Buddhism without discarding the old way of thinking and behaving by approving the indigenous religion.

While Buddhism recognizes the similarity between itself and the indigenous religion, it also emphasizes its superiority over the other. Monks approach people of the indigenous religion spontaneously by making use of the already familiar views of spirits and the otherworld. But they eventually differentiate Buddhism from the indigenous religion, which Buddhists claim to be insufficient and inadequate, and proclaim Buddhism to be the true and perfect way. Buddhist priests whom I met argued that the shamanic religion offers neither a true understanding of the world nor a proper way of salvation. They asserted that the indigenous religion misses the essentials that are necessary for helping people become free from suffering and that people can obtain these essentials only through Buddhism. For them, Buddhism offers the real truth that the indigenous religion does not have.

It should be noted that the rituals transformed into Buddhist style declare the superiority of Buddhist cosmology and theology. The performance of these rituals in a Buddhist way is based on the idea that the Buddha or other Buddhist sacred beings are more powerful than the gods of the indigenous religion. While converts to Buddhism in Jeju do not deny the existence of the indigenous gods, they believe that reciting Buddhist sutras and praying to the Buddha are more effective than offering services to indigenous gods. Though they acknowledge myths and rituals of the indigenous religion, they regard it as inferior to those of Buddhism. Yowangje performed in a Buddhist style is based on the assumption that Buddha can be implored to command the indigenous sea god. People who have domestic rituals conducted by Buddhist monks believe that the old gods of the house can be controlled or even sent to the other world by reciting Buddhist sutras.

5 Removing the symbolic body of domestic gods from the house was very rare before the modernization movement in 1960s and 1970s. Since the modernization movement, people of Jeju began to build houses without backyards and storerooms where important domestic gods were thought to be reside. 
Buddhism has the most powerful mechanism for proselytizing because it has similar cosmologies to those of the indigenous religion and also because it successfully persuades people to recognize Buddhism as an institutionalized "higher" religion, not "superstition." Buddhism is the most powerful challenger to the indigenous religion due to these similarities. Some scholars point out that it is Buddhism rather than Christianity that weakens the indigenous religion in the rural areas of Jeju (Cho et al. 2003, p. 375). They indicate that the influence of the indigenous religion began to wane from the period when the intensive construction of Buddhist temples began in Jeju and more conspicuously in areas where the number of Buddhist temples increased. It is obvious that Buddhism has had more converts from the indigenous religion than any other religion over the last 100 years.

It is obvious that Confucianism and Buddhism, the former in the past and the latter recently until the present, have successfully persuaded Jeju people to accept their similarity to the Jeju shamanic religion. In other words, they have succeeded in persuading people to acknowledge the value of the new religious teachings and rituals. It was not difficult for them to appreciate the indigenous religion because they shared similar cosmologies. Nonetheless, simultaneously, these two religions did not forget to differentiate themselves from the indigenous shamanic religion by emphasizing their own identities.

\section{3. "Similar but Superior" Rhetoric of Christianity in Jeju}

Unlike Confucianism and Buddhism, Christianity in Jeju has not directly argued for similarity between religions. However, we can find its "similar but superior" rhetoric in the two cases I will describe. First, Kim Wonyeong, the first Korean parish priest in Jeju (1899 1901), introduced and propagated Catholic doctrine by emphasizing its similarities to Confucian ideas while articulating Catholic superiority. Second, contemporary Catholics and some Protestants in Jeju try to develop ritual processes that are similar to those of the traditional Korean religions to approach Jeju people and lower their resistance to these rituals.

\subsection{The Rhetoric of Catholicism in the Early Years}

Unlike Confucianism and Buddhism, which share a similar ritual system and worldview with the indigenous shamanic religion, Christianity, which has totally different rituals, cosmology, and soteriology seemed very unfamiliar to Koreans. Naturally, in Korea, Christianity that came from the West has been considered relatively more foreign than Buddhism and Confucianism that have been coexisting harmoniously with the indigenous religion for a long time. That is why the first Korean Catholic priest of Jeju, in his treatise Susin yeongyak, which can be translated as "miraculous medicine for cultivating the body," had to remind his readers in Jeju who criticized Christianity for being a foreign religion that Buddhism and Confucianism also came from abroad.

Christianity was first introduced to Jeju when the court of Joseon persecuted Catholics and exiled some of them to Jeju in 1801. Due to continual persecutions by the government, however, it was not until 1899 that a Jeju Parish was founded, which was raised to the Jeju Diocese in 1977 (Jeju Seongyo Baekjunyeon Ginyeom Saeop Wiwonhoe 2001, pp. 31-71). The Protestant mission work began in earnest in 1908 when one of the first seven ordained Korean pastors was sent to Jeju as a missionary. Prior to this period, it is believed that there had been only a few Jeju indigenous people who converted to Protestantism during their visit to the mainland (Yi 2008a, pp. 30-31; Park 2008, pp. 138-45).

From the outset, the Christian method of proselytizing the indigenous residents involved encouraging them to give up traditional local customs and accept the Western Christian worldview. For the first two years after the parish was founded, the Jeju parish church engaged in very aggressive proselytism. But this aggressive way of proselytization caused many people's antipathy toward the Catholics. Some early Catholics of Jeju not only felt superior to non-Christian residents but also regarded the indigenous religion as evil and something to be eliminated. This arrogant attitude of Catholics roused the antipathy of many Jeju people. Conflicts between the Catholics and those 
opposing it led to a popular armed uprising in 1901 (Go 2000, pp. 335-44). According to several records of that time, many people in Jeju thought that the early Catholics of Jeju were very arrogant and often harassed people by relying on the power of foreigners from the West (see Park 2008, p. 112). When Catholics were hired for collecting tax from the indigenous people, resistance against the former reached its peak. Catholic tax collectors were being unfair, harassing many people. The uprising that resulted in the death of about 350 Catholics demonstrates how arrogant the first generation of this religion in Jeju had been perceived and how aggressive their way of propagation had been felt to be (Jeju Seongyo Baekjunyeon Ginyeom Saeop Wiwonhoe 2001, p. 89; Park 2008, pp. 117-22).

But the early Catholics of Jeju were very successful in converting many people in a short period of time. Just two priests, one French and one Korean, converted more than 1500 people in less than two years. It would have been impossible for the Catholic church to grow if it had not been so persuasive in convincing people of the rightness of its teaching, though some converts may have been attracted by the powerful authority of the priests.

The persuasive arguments of the Catholics for proselytizing Jeju people are most clearly seen in Susin yeongyak, which was written by Priest Kim Wonyeong (see Kim 2001, pp. 757-99). In this writing, while Kim firmly criticizes preexisting religions, he also tries to show that Catholicism is not very alien to Jeju people but based on the familiar worldview that they can accept without difficulty, by emphasizing some common ground between Catholic doctrines and Confucian ideas.

Among the preexisting religions, the indigenous shamanic religion is most harshly attacked by him. While he categorizes Confucianism and Buddhism as "do" (way, principle) or "gyo" (teaching or religion), the indigenous religion is called "heathenism" (Kim 2001, p. 792). 6 To him, shamanic rituals and divinations are noted as neither trustworthy nor efficacious. He gravely condemns the practice of worshipping the serpent god and respecting serpents. He maintains that the people of Jeju have been deceived by simbang even though they claim to have been relieved of illness after healing rituals performed by them. According to Kim, expected results become actualized only sporadically and by accident. Giving a detailed description of 21 domestic and communal shamanic rituals, which continue to be conducted in Jeju at present, he strongly criticizes the procedures and related myths of each ritual. Purity and pollution rules associated with shamanic rituals are also criticized.

He also criticized customs of Jeju that he thought were immoral from the perspective of a Catholic priest. He especially attacked the practice of keeping many concubines as well as drinking alcohol. He claimed that drinking a very small amount of alcohol is permissible but it is better to completely stay off alcohol. ${ }^{7}$ He argued that people should be eager to get the faith which is the medicine for the soul, not just medicines for the body that come from the West. It appears that he gave medicines and other goods from the West to the people, though he rebuked some people who wanted to get only the benefits including money from the church without any interest in conversion.

Priest Kim repeatedly cites Confucian classics in order to persuade readers to believe in the Christian God and cosmology. This was a common strategy for Catholics when proselytizing East Asians. It is well known that European missionaries who had come to China from the $16^{\text {th }}$ century tried to explain the existence and attributes of God by comparing Christian doctrine with Confucian classics. In mainland Korea in the late 19th century, Priest Choe Yangeop and several other priests often cited Confucian classics in order to introduce the Catholic doctrine. It was possible because Korean priests including Kim Wonyeong were well versed in Confucianism.

Priest Kim appropriates the ideas of Confucianism and its traditional cosmology that sound similar to those of Christianity. He uses the concept of "the Great Emperor of Heaven" or "heaven"

6 It is noteworthy that Kim did not directly attack Buddhist rituals or doctrines though he mentioned Buddhism a few times. For instance, he talked about Buddhism when he pointed out that Buddhism and Confucianism were originally from foreign countries, as well as Christianity. I think this proves that Buddhism was not influential around 1900 as I said above.

7 Later the Korean Catholic church became more flexible regarding the drinking of alcohol. It is not uncommon to see priests drink alcohol with members of their parish churches. 
from the Confucian classics and Korean traditional proverbs to persuade people to believe that there is one supreme God who is the master of the universe. When he explains the relationship between human souls and bodies, he quotes Mencius and mentions three basic principles in human relations and five constant virtues. He supports his criticism against indigenous rituals and customs by suggesting examples of Confucius and some ancient Chinese sage kings.

Priest Kim repeatedly suggests facts, concepts, and terms that are familiar to Koreans in Susin yeongyak to make his arguments sound persuasive. He supports his assertion that it is possible to undermine the indigenous religion by suggesting examples of two officials of Jeju, Yi Hyeongsang and Seo Rin, who persecuted and tried to weaken the indigenous religion. To refute the criticism that Christianity was a foreign religion, he recalled that Buddhism and Confucianism were also imported from foreign countries to Korea. In addition, he mainly emphasized the Christian doctrines concerning the Lord of Heaven and referred to the Holy Mother Maria several times. But he does not explain about the son of God, Jesus. He mentions Jesus once very briefly in a prayer in the introductory part and twice when he refers to "the miracles of the name of Jesus" (Kim 2001, pp. 758, 773, 777). It seems that he wanted to avoid a difficult explanation about the son of God who was born as a human being, a concept which does not have any parallel in traditional Korean thought. Kim was trying to persuade Jeju people by appropriating traditional oriental cosmology and theology.

Though Priest Kim appropriates Confucianism for the basis of his argument, he makes a clear differentiation between Catholicism and Confucianism, declaring the superiority of Catholicism over Confucianism. While defending Christian doctrines against the criticism that Christianity does not practice filial piety, which is one of the most important elements of Confucianism, he asserts that believing and serving the master of heaven is the real filial duty. He also criticizes the ancestral rites, harshly attacking processes of calling and sending back spirits of the dead and bowing down to these spirits. He argues that the contemporary people are not obeying the teachings of ancient Confucian saints to serve a "great parent" of heaven and that Jeju people should serve the heavenly Lord if they want to attend to their dead parents. According to him, true offerings should be dedicated only to the God of heaven, which is possible only through the Catholic Church (Kim 2001, pp. 764-66, 777-78).

\subsection{The Case of the First Protestant Pastor in Jeju}

As we have seen, in Susin yeongyak, Priest Kim not only criticized the practices and ideas of preexisting religions that the Catholic church could not accept but also tried to introduce Christian doctrine to Jeju people by using traditional thoughts that were familiar to Jeju people. The Protestants also, from the first, articulated that only they could offer the way to salvation. But the Protestants did not emphasize similarities between Protestantism and preexisting religions, as witnessed by the ministry of Pastor Yi Kipung, the first Protestant missionary of Jeju. Pastor Yi went to Jeju nine years later than the Catholics did. He went there by himself without any foreign missionary to rely on. And as Japanese colonization of Korea was just beginning at that time, he could not rely on the government's respect for the West and Christianity either. In addition, many indigenous people of Jeju had antipathy against Christianity since the conflicts with Catholics that had reached their peak during the popular uprising in 1901. Therefore, he could not be as influential as the first Catholic priests and was more vulnerable to harassment by those who were against Christianity. He was attacked many times, and once narrowly escaped from being killed when people assaulted him for disrespecting traditional Jeju practices including shamanic rituals (Yi 2008b, pp. 98-100; Seongan Gyohoe Baeknyeonsa Pyeonchanwiwonhoe 2010, pp. 104-18). Pastor Yi strictly disapproved of the indigenous and Confucian rituals that were against the Christian doctrine. That is why the first lay members of his church who refused to participate in ancestral rites experienced severe hardship in their family (Yi 2008b, pp. 107-8). He developed a movement for removing serpent figurines from houses, reproaching the shamanic tradition of serving the serpent god and actual serpents (Yi 2008b, pp. 93, 97; Chang 2008, pp. 78-104). 
This aggressive attitude of Pastor Yi does not look so different from that of the early Catholics of Jeju. However, there is no evidence that shows Pastor Yi's appropriating Confucian or traditional worldviews in order to explain Christian doctrines as Priest Kim did. The common theme of three sermons by him, of which manuscripts were handed down to his daughter Yi Sarye, is the matter of human sin and atonement by Jesus Christ (as included in (Yi 2008b, pp. 213-34)). Pastor Yi Dojong, whom Yi Kipung converted to Protestantism from the Jeju indigenous religion, said that Yi Kipung preached about Jesus Christ (Park 2009, p. 100). Yi Sarye also remembered that the main focus of her father's sermons was "Jesus Christ, the only way of our salvation" (Yi 2008b, pp. 103-10). Pastor Yi's sermons contrast sharply with Susin yeongyak in which Priest Kim scarcely mentions Jesus and explains Catholic doctrines by comparing them with traditional ideas on the world and the gods. Pastor Yi, who was an evangelical Protestant missionary, directly dealt with a theoretical theme that was unfamiliar to Jeju people.

Pastor Yi did not try to make Protestantism look familiar to Jeju people by emphasizing its similarity with preexisting religions. But because he was a very enthusiastic and charismatic evangelist, he could gradually proselytize Jeju people. In 1913, after five years of missionary work, there came to be eight churches and an average of 400 regular church-goers in Jeju (Park 2008, p. 174).

\subsection{Developing Ritual Processes Similar to Those of Traditional Religions}

Catholics could be comparatively more successful in Jeju than on the mainland, partly because of their contribution to the development of the economy and the welfare of Jeju people. The Jeju Parish has been running schools since 1946, and now the Jeju Diocese runs six kindergartens, a middle school, and a high school. In the late 1950s and early 1960s, Priest P. J. McGlinchey, who came from Ireland, conducted a campaign for agrarian development, under the motto "Preventing Poverty: A New Way of Mission." He helped the people of Jeju receive financial support from European and American Catholic organizations. His campaign led to improvements in land and livestock, and the development of various domestic industries. It was also Priest McGlinchey who introduced credit unions to the local communities of Jeju. Though the number of Catholics did not explosively increase during this period, the public image of Catholicism remarkably ameliorated. Since the campaign of McGlinchey, the Catholics of Jeju have developed "many new ways of mission." For the inhabitants of Jeju, they have founded many welfare facilities including a clinic and community center for senior citizens, nursing homes, farms, and fertilizer plants (Jeju Seongyo Baekjunyeon Ginyeom Saeop Wiwonhoe 2001, pp. 169-71, 206-11, 218, 260-300).

Another reason, which is more important for the theme of this paper, is that Jeju people have been impressed by indigenized Catholic rituals. Not only in Jeju but also in the whole of South Korea, Catholics have accepted important elements of central rituals of preexisting religions, especially those dealing with the dead. These indigenized rituals have accommodated many elements of Confucianism, Shamanism, and Buddhism. Many Jeju people who had cherished the traditional ritual system and worldview could approach the church without feeling guilty.

First, ancestral rites were approved by the Catholic church after the Second Vatican Council. Even before the council, during the first half of the 20th century, these rites were beginning to be accepted by the church as some kind of expressions of filial piety. After the council, only the ritual procedure of calling spirits of the dead and sending them away became prohibited and Catholic participants have been asked to recite Psalms and prayers instead. Other important procedures including offering food while bowing down to dead ancestors remain in Catholic ancestral rites. This was a great change considering that the principal reason for the Joseon government's persecution of the Catholics was their refusal of ancestral rites.

Second, the Korean Catholic church offers a funeral service that appeals to many Koreans. The church says that this indigenized funeral service makes great contributions for the Catholic missionary work. It is natural for Jeju people who are very concerned about the life after death and ancestral rites to come to have interests in Catholic funerals. Many non-Catholic Koreans think highly 
of Catholic funerals in which priests and lay persons devotedly assist in proceedings and burials. It is remarkable that most parish churches in Jeju have a funeral hall. According to Hyeon, not a few Jeju people who cannot afford to have a family burial plot decide to become a member of Catholic church without knowing even "The Lord's Prayer" or "The Ten Commandments" in order to be buried in the cemetery of a parish church (Hyeon 2009, p. 205).

The Catholic funeral service is said to have the most indigenized form among the Korean Catholic rituals. Church members ceaselessly recite prayers in turn in a rhythm and tone that resemble traditional Korean chanting. Respecting a Buddhist tradition of sending spirits of the dead to the otherworld on the 49th day after death, Korean Catholic churches hold a mass on that day in memory of the deceased. If the family of the dead person wishes, performing any type of the traditional funeral process, including bowing down to the dead body, is allowed as long as it is not manifestly against the Catholic doctrine. According to the two Jeju native Catholic priests I interviewed, the Catholic funeral service that meets people's tastes and needs has helped increase the number of Catholic converts in Jeju.

The Protestant church in Jeju has not been as successful as in the mainland. As I mentioned above, the Protestants have neither exerted any effort to make Jeju people feel familiar with Protestantism nor contributed to improving the quality of their life. Until recently, Jeju was the only province with neither a hospital nor authorized school established by protestant organizations. By contrast, many schools and hospitals have been founded on the mainland since the first hospital and the first modern school of Korea were founded by a protestant denomination in Seoul in 1885. Jeju has been excluded from the support of Korean protestant churches.

Some protestant pastors of Jeju, nevertheless, try to find ways to approach people by making Christianity look familiar to Jeju people. They argue that the Protestant church should try to use ideas familiar to Jeju people in order to explain doctrines, to accommodate where possible traditional rituals, and to seek out ways to contribute to Jeju society. I interviewed one of these pastors, a Presbyterian, who wanted to follow the example of the Catholics.

The first aim of this pastor is to find ways to contribute to Jeju society to win Jeju people's favor. He is an award-winning painter, with a Ph.D. from the Graduate Theological Union in the United States. He is well known to Protestants in Jeju for his public lectures and local newspaper columns. In spite of this distinguished career, he has been carrying out his ministry only in rural areas. He wants to use his career to find "a new way of mission" just as the Catholic priest McGlinchey did. He has been very successful multiplying the number of members by five-fold at two churches that he had taken over from other pastors. "Preventing poverty," the slogan with which priest McGlinchey rallied the poor of Jeju right after the Korean War, is outdated now since Korea has achieved great economic growth. Hence, my interviewee has decided to appeal to the cultural and educational interests of the people. He invites artists to his church to hold free music concerts and art exhibitions for community people. He offers free art classes at times and free English classes regularly to the children of the community. His wife, who studied the violin at college, also teaches villagers music. The Protestant church will surely have to do more voluntary service to expand successfully in Jeju.

Furthermore, he seeks for ways to attract people who cannot easily give up rituals of the preexisting religious tradition, as the Catholic church has been doing. First, he holds wedding ceremonies as well as celebration parties at the church yard, which look similar to the traditional Korean wedding ceremony. Second, he recognizes a need to design and wear a special funeral robe that looks like a garment worn by officiants of Confucian-shamanistic funerals. Finally, he argues that Protestant churches, especially those of Jeju rural areas, have to develop a memorial service which reminds people of traditional ancestral rites. For instance, on the anniversaries of ancestors, the Protestant church can encourage the people of Jeju to prepare the same food that is put on the ancestral rites table and to place the dead person's portrait on the table. More and more Protestants in Jeju, including conservative ones, support his attempts to approach non-Protestant people. 
However, he and other Protestants of Jeju make it clear that they can accommodate indigenous or traditional elements in ancestral rites and funerals as long as Protestant doctrines are not undermined. Namely, though he is willing to accept some aspects of preexisting religions, he also wants to articulate the difference and superiority of Protestantism. In this sense, he is repeating the rhetoric that has been employed by Confucianism, Buddhism, and Catholicism.

\section{View of the Indigenous Shamanic Religion on Other Religions}

Simbang have not systemically explained the relationship of the indigenous religion with other religions in Jeju. Bonpuri, Jeju myths that simbang recite during indigenous rituals, should be referred to in order to understand their attitude to Buddhism and Confucianism (for recorded texts of recited bonpuri, see (Hyeon 2005; Kim et al. 2006; Hyeon 2007; Mun et al. 2010)). Bonpuri reflect the thought and customs of Jeju people, not only of the period of Mongolian rule and the early Joseon Dynasty but even of the early 20th century. It is believed that the current shape of bonpuri has usually been composed by putting together various stories, from ancient myths to anecdotes of the late $19^{\text {th }}$ or the early $20^{\text {th }}$ century (See Hyeon 2009, pp. 65-66).

But bonpuri is not sufficient material for understanding shamanic views on other religions. They do not mention Christianity at all and include only fragmentary ideas of Buddhism and Confucianism. For this reason, I tried to gather the opinions of simbang on this matter. I found that the four simbang I met for this purpose suggested roughly similar ideas on other religions. They recognized the similarity between the indigenous religion, Buddhism, and Confucianism but they expressed a strong sense of incompatibility with Christianity. Though they acknowledge the social coexistence with Christianity, they regard Christianity as having a different worldview that they cannot share. Some of them said that Jeju indigenous people would be in trouble if they go to a Christian church and follow its teaching. Simbang have not given consideration to ways of accepting or recognizing any elements of Christianity, while some Catholic and Protestant leaders of Jeju have tried to do so.

The view of the indigenous religion on Buddhism and Confucianism is more complicated than that on Christianity. Of course, there are not a few passages in bonpuri that not only acknowledge the existence of Buddhism and Confucianism in Jeju but also seem to recognize their advantages. The social order and virtues that Confucianism emphasized during the Joseon period are appreciated in many bonpuri. Loyalty to the king, filial piety, authority of magistrates sent by the government, male-centered ideas and practices, and many other Confucian virtues are in the background of most bonpuri, which of course are often satirized from the people's viewpoint. Some bonpuri show more direct influence of Confucianism. For example, the name of the father of the Jetbugi (errand boy) three brothers, the main characters of Chogong bonpuri, is "Juja seonsaeng," which means Mr. Zhu Xi. Zhu Xi, one of the sages revered by Korean Confucian scholars, is accepted as the father of indigenous gods in Jeju mythology. Another example is to be seen in Sehwa bonhyangdang bonpuri, in which Cheonjatto, the main god of Sehwa village, is described as an excellent student of Confucianism. After finishing the Thousand-Character Classic at the age of seven, he masters a textbook for children written by several Confucian scholars in the mid-Joseon period, a Chinese history book from the $11^{\text {th }}$ century, and finally the Four Books and Five Classics. This story of mastering of Confucian texts, which the general people of Jeju of the Joseon period seldom heard of, seems to be inserted in order to emphasize the god's outstanding knowledge. Influential simbang of the late Joseon period, who played roles in the formation of bonpuri as they are now, took the coexistence with Confucianism for granted.

Though Buddhism was not active in Jeju during the Joseon Dynasty, the indigenous religion must have been influenced by Buddhism from the period of Mongolian rule which was before Joseon was founded (Hyeon 2009, pp. 86-87, 147-48, 170-72, 261-66). Seeing that the influence of Buddhism is repeatedly mentioned in bonpuri (see Hyeon 2005, Chapters 3, 4, 5, 9, 11; Mun et al. 2010, Chapters 2, 3, $6,9,11)$, it is clear that Buddhism was not a new and unfamiliar religion to Jeju people in the early $20^{\text {th }}$ century when Buddhist monks recommenced establishing temples and propagating them. We can 
easily find the examples of Buddhism's influence on the indigenous religion in bonpuri, which indicate Jeju indigenous myths.

First, the Buddha appears as the ancestor of the indigenous deities or the name of the Buddha is used for the indigenous deities. The ancestors of the main characters of Chogong bonpuri, Chilseong bonpuri, and Handong bonhyangdang bonpuri are said to be the Buddha. The genealogy of the Jetbugi brothers in Chogong bonpuri is especially noteworthy. I already wrote that their father is said to be Zhu $\mathrm{Xi}$. And the name of their grandfather is introduced as Seokga yeorae (Sakya-tathāgata) and that of their grandmother as Seokgamoni (Sakyamuni). The highest being in Buddhism is invited to become ancestors of the indigenous deities. In that the two different names of the identical being, the Buddha, are used to indicate two distinct god and goddess, it can be said that exact knowledge of Buddhism was not important to both those who inserted these names and those who accepted them in their myth. Another example of the Buddhist influence is witnessed in the nickname of the childbirth goddess Samseunghalmang, which is "the living Buddha king (or queen)."

Second, Buddhist monks are often regarded as sacred beings. They are depicted as having supernormal power that ordinary people do not have in Chasa bonpuri and Godaejang bonpuri; according to Namdang bonpuri, the main god of Haengwonli village was originally a Buddhist monk; stories of a childless couple, who come to get children by offering a Buddhist service, are often included in introducing parts of some bonpuri, such as Chogong bonpuri, Igong bonpuri, Segyeong bonpuri, Chilseong bonpuri, and Woljeong bonhyangdang bonpuri. It is clear that these indigenous myths recognize the effectiveness of Buddhist rituals.

While individual simbang are usually aware of the similarities between the three religions, they put more stress on their superiority. I interviewed a simbang who has been working as a shaman for about 40 years and whose grandfather and father had also been simbang. Though he acknowledges the abovementioned similarities between the three religions, he deplores the situation in which Buddhist monks are taking over the works of simbang. He argues that it is not ritually proper for Buddhist monks to serve as an intermediary for worshiping shamanic gods. His criticism is similar to what had been pointed out by Confucian officials of Joseon, mainly in relation with the issue of eumsa, which, as mentioned above, refers to rituals conducted against the proper procedure or those offered to undeserving spirits. Other simbang that I met in Jeju likewise said that although Buddhism and their indigenous religion are similar, their religion is the right way to please the gods and goddesses of Jeju. All simbang I interviewed believe that Jeju people can be in trouble if they keep resorting to Buddhist monks instead of coming to simbang. Though they did not suggest any logical grounds, they claimed supremacy of the indigenous religion over other religions at least for Jeju people, in spite of the similarities. Their stance is not different from that of Buddhist monks who argue that the indigenous religion cannot offer the right way of escaping suffering or a proper understanding of the world.

The Jeju indigenous shamanic religion basically acknowledges the similarity of the indigenous religion to Buddhism and Confucianism, which are acknowledged in not a few indigenous myths. At the same time, simbang also argue that only their own religion can offer the perfectly true and right way for understanding the order of the world or for enjoying peaceful lives.

\section{Conclusions}

Having found ways to harmoniously coexist with the indigenous shamanic religions, Confucianism and Buddhism have been able to persuade many people, who used to solely rely on the indigenous religion, to accept their new ideas and practices. Confucianism did so in the 19th century and Buddhism since the early 20th century. That the indigenous religion and the two old, foreign religions have similar views on death and spirits has made it rather easy for the followers of the indigenous religion to convert to Confucianism and Buddhism. Furthermore, the communal and domestic rituals of each tradition can be conveniently replaced with one another's. Thanks to these similarities, the two religions could coexist with the indigenous religion without much difficulty. But Confucianism and 
Buddhism have not regarded it as providing the proper way of keeping the order of the universe or attaining salvation. The two religions articulated their superiority over other religions in Jeju.

It is true that many elements of the preexisting religious tradition were unacceptable to the Christian worldview and vice versa. It is not only because Christianity came into Korea later than the two other imported religions, but also because the three religions share similar worldviews and a loosely unified ritual system. Thus, the two religious systems, namely Christianity and the three traditional religions, have rejected each other, marking a limit to the tradition of peaceful coexistence that has been characteristic for the island's religious communities. The Christian method of proselytizing the indigenous residents involved encouraging people to give up traditional local customs and accept the Christian worldview. However, Christianity has also tried to find and exploit the interface between itself and other religions. One way that this method has been carried out is through the missionaries' appropriation of the traditional Confucian worldview which resembles the Christian one. The Catholics gradually and successfully reduced their own antipathy against indigenous religious elements, by approving of domestic rituals and emphasizing the grandeur of their funeral ritual. Even though Protestants have been slow in accepting and appreciating traditional views and rituals, many of them nowadays agree that they should respect the religious sentiment of Jeju people and develop ritual processes that can appeal to them. It should be noted that this effort of Christianity to find ideas and practices that it can appreciate and accept has also been made for the purpose of proselytization. Though both Catholics and Protestants try to make themselves look familiar to the Jeju local people by emphasizing the similarities, both of them hold fast to the belief that only they can offer the right understanding of the world and the effective way for the salvation of human beings.

Therefore, religions of Jeju that try to make themselves look familiar to people often appreciate other religions and accept other religions' elements that may harmonize with their own ideas and practices. We can see that the outside religions have tacitly and indirectly appreciated certain elements of the indigenous religion. In order to attract the local population, which was strongly attached to this indigenous religion, the imported religions in Jeju have recognized at least some "partial truth" in shamanism and have appropriated it for the rhetoric of coexistence. Moreover, in one way or another, they have recognized the importance of some rituals of preexisting religions which were not easily separable from the people. Confucianism and Buddhism have accepted some ritual processes of shamanic religion into their own; Catholicism has approved of some traditional rituals which it used to reject and criticize harshly; even some Protestants have tried to accommodate or imitate traditional rituals. In short, religions of Jeju compare themselves with other religions, emphasize some elements of others that they can approve, and try to make themselves look familiar to the people they try to attract. Simultaneously, each religion differentiates itself from others and asserts its superiority over others, though it appreciates some partial value or truth of other religions. They have asserted that other religions' partial truth and limited value show the sharp contrast with the complete truth and value of their own, and that only they can provide the proper way of keeping the order of the universe or attaining salvation of human beings. This common rhetoric that my religion is similar but superior to other religions has been repeatedly emphasized in Jeju, in order to persuade people outside the religion to accept or at least approve it without compunction and at once to reinforce the insiders' conviction to stay in it.

Funding: This research received no external funding.

Conflicts of Interest: The author declares no conflict of interest. 


\section{References}

Chang, Harim. 2008. The Life and Faith of Pastor Yi Kipung 2 [Yi Gipung Moksa-ui Sam-gwa Sinang 2]. Seoul: JCR Kids, ISBN 9788992758369.

Cho, Seongyun. 2005. “Joseon Sidae Jejudo Ingu-ui Byeonhwa Chui” [Population Changes in Jeju-do during the Joseon Period]. Tamramunhwa 26: 53-70. Available online: http://kiss.kstudy.com/thesis/thesis-view.asp? key=2710180 (accessed on 23 March 2020).

Cho, Seongyun, Sangcheol Lee, and Sunae Ha. 2003. The Structure and Changes of Popular Belief of Jeju Region [Jeju Jiyeok Mingan sinang-ui Gujo-wa Byeonyong]. Seoul: Baiksanseodang, ISBN 9788973273126.

Choe, Jongseong. 2007. Joseon Jeongi Jonggyo Honhap-gwa Ban-honhapjuui: Yugyo, Bulgyo, Musok-eul Jungsimeuro [Religious Syncretism and Anti-Syncretism of Confucianism, Buddhism, and Korean Shamanism in the Earlier Joseon Dynasty]. Jonggyo Yeongu 47: 37-81. Available online: https://www.kci.go.kr/ kciportal/ci/sereArticleSearch/ciSereArtiView.kci?sereArticleSearchBean.artiId=ART001062602 (accessed on 23 March 2020).

Go, Seonghun. 2000. Age of Uprisings: Uprisings and Upheavals of the Joseon period [Millan-ui Sidae: Joseon Sidae Millan-gwa Byeonllandeul]. Seoul: Garamgihoek, ISBN 8984350281.

Hyeon, Yongjun. 2005. Myths of Jeju-Do [Jejudo Sinhwa]. Seoul: Seomoondang, ISBN 9788972434191. First Published 1976.

Hyeon, Yongjun. 2007. Dictionary of Sources on Jeju Shamanism [Jejudo Musok Jaryo Sajeon]. Jeju: Gak, ISBN 9788989719977. First Published 1980.

Hyeon, Yongjun. 2009. Lives of Jeju People [Jejudo Saramdeul-ui Sam]. Seoul: Minsokwon, ISBN 9788956387918.

Jeju Seongyo Baekjunyeon Ginyeom Saeop Wiwonhoe [Jeju Mission Centennial Memorial Committee]. 2001. Jeju Cheonju Gyohoe Baeknyeonsa [The History of 100 years of the Jeju Catholic Church]. Jeju: The Jeju Diocese.

Kim, Heonseon, Yongjun Hyeon, and Jeongsik Gang. 2006. A Research on Myths of Jeju Ancestor Deities [Jejudo Josangsin Bonpuri Yeongu]. Seoul: Bogosa, ISBN 8984334332.

Kim, Dongseop, Sundeok Mun, and Yeongja Yang. 2007. Korean Family Worship: Jeju-do [Hanguk-ui Gajeong Sinang: Jejudo Pyeon]. Daejeon: National Research Institute of Cultural Heritage, ISBN 9788981248307.

Kim, Wonyeong. 2001. Miraculous Medicine for Cultivating the Body [Susin Yeongyak]. Translated by Yeonghwan Kim. In the appendix of Jeju Cheonju Gyohoe Baeknyeonsa. Jeju: The Jeju Diocese, pp. 757-99. First Published 1900.

Mun, Mubyeong, Yeongja Yang, and Suni Kim. 2010. Jeju Sinhwajip [A Book of Jeju Myths]. Jeju: Jejumoonhwawon, ISBN 9788994168135.

Park, Yongkyu. 2008. History of Jeju Christian Church [Jeju Gidokgyohoesa]. Seoul: Saengmyeonguimalsseumsa, ISBN 9788904060306.

Park, Eunbae. 2009. The Dwelling of the God [Hananim-ui Geocheo]. Seoul: Saeroun Saramdeul, ISBN 9788981203849.

Seongan Gyohoe Baeknyeonsa Pyeonchanwiwonhoe. 2010. History of Jeju Seongan Church 100 years [Jeju Seongangyohoe Baeknyeonsa]. Jeju: Jeju Seongangyohoe, ISBN 9788995445389.

Smith, Jonathan Z. 1990. Drudgery Divine: On the Comparison of Early Christianities and the Religions of Late Antiquity. Chicago: University of Chicago Press, ISBN 0226763625.

Smith, Jonathan Z., ed. 1995. The HarperCollins Dictionary of Religion. New York: HarperCollins, ISBN 0060675152.

Smith, Jonathan Z. 2004. Relating Religion: Essays in the Study of Religion. Chicago: University of Chicago Press, ISBN 0226763870.

Statistics Korea. 2016. 2015 Population and Housing Census Report. Available online: http://kosis.kr/statisticsList/ statisticsListIndex.do?menuId=M_01_01\&vwcd=MT_ZTITLE\&parmTabId=M_01_01\#SelectStatsBoxDiv (accessed on 2 August 2019).

Tu, Wei-Ming. 1993. Confucianism. In Our Religions. Edited by Arvind Sharma. New York: HarperCollins Publishers, ISBN 0060672641.

Walraven, Boudewijn. 1999. Popular Religion in a Confucianized Society. In Culture and the State in Late Choson Korea. Edited by JaHyun Kim Haboush and Martina Deuchler. Cambridge: Harvard University Asian Center, ISBN 067417982X.

Yi, Hyeongsang. 2009. Namhwanbakmul [Broad Knowledge of Jeju]. Translated by Sangkyu Lee, and Changmyeong Oh. Seoul: Pureunyeoksa, ISBN 9788991510869. First Published 1704.

Yi, Manyeol. 2008a. Yi Gipung Moksa-ui Haengjeok [The Deeds of Pastor Yi Kipung]. In Yi Gipung: Sungyoro Salm-eul Magamhan Choecho-ui Seongyosa. Edited by Sarye Yi. Seoul: Gidokgyomunsa, pp. 11-40. 
Yi, Sarye. 2008b. The First Korean Missionary Martyr Yi Kipung [Yi Gipung: Sungyoro Salm-eul Magamhan Choecho-ui Seongyosa]. Seoul: Gidokgyomunsa, ISBN 9788946615588.

Yoo, Yohan. 2012. Jeju Tochakjonggyo-wa Oeraejonggyo-ui Galdeung-gwa Jilseohyeongseong Gwajeong-e Gwanhan Yeongu [Conflicts and Coexistence of Native Religion with Imported Religions in Jeju Island]. Jonggyo-wa Munhwa 22: 1-36. Available online: http://kiss.kstudy.com/thesis/thesis-view.asp?key=3073325 (accessed on 23 March 2020). 